\title{
PENGARUH PEMBERIAN DOSIS DAN FREKUENSI BIOFERTILIZER TERHADAP KADAR KLOROFIL DAUN BIBIT SENGON (Paraserianthes falcataria (L.) Nielsen)
}

\section{THE EFFECT OF DOSES AND FREQUENCY OF BIOFERTILIZER ON THE CHLOROPHYLL CONTENT IN SILK TREE LEAVES (Paraserianthes falcataria (L.) Nielsen)}

\author{
Dwimei Ayudewandari Pranatami, Sekar Arum \\ Institut IImu Kesehatan Bhakti Wiyata Kediri \\ dwimei_ayudewandari@yahoo.com
}

\begin{abstract}
Abstrak
Klorofil merupakan komponen penting yang dibutuhkan dalam fotosintesis, dimana pembentukanya diperlukan suplai zat hara seperti nitrogen dan fosfat. Suplai zat hara tersebut dapat dibantu dengan pemberian biofertilizer yang mengandung bakteri fiksasi nitrogen, bakteri pelarut fosfat dan mikroba dekomposer. Penelitian ini bertujuan untuk mengetahui pengaruh dosis dan frekuensi pemberian biofertilizer terhadap kadar klorofil bibit sengon (Paraserianthes falcataria (L.) Nielsen). Penelitian terdiri atas 2 perlakuan kontrol dan 8 perlakuan uji. Seri dosis biofertilizer yaitu 20,40,60, dan $80 \mathrm{~mL} /$ tanaman dengan frekuensi pemberian 1 minggu sekali dan 2 minggu sekali. Mikroba dalam biofertilizer terdiri atas Azotobacter chroococum, Azospirillum brasilense, Rhizobium leguminosarum, Bacillus subtilis, B. megaterium, B. licheniformis, Pseudomonas fluorescens, P. putida, Cellvibrio mixtus, Cellulomonas cellulans, Cytophaga saccharophila, Lactobacillus plantarum, dan Saccharomyces cerevisiae. Penelitian ini menggunakan rancangan acak lengkap (RAL) dan data dianalisis menggunakan uji ANAVA satu arah dengan uji lanjutan yaitu uji Duncan dan uji Brown -Forsythe serta uji Gomes Howell pada taraf $5 \%$. Hasil penelitian menunjukkan bahwa pemberian dosis dan frekuensi biofertilizer berpengaruh nyata dalam peningkatan kadar klorofil daun. Pada K+f1 $(65.28 \pm 1.07 \mathrm{mg} / \mathrm{L})$ menunjukkan kadar klorofil tertinggi dan berpengaruh secara signifikan dibanding dengan lainnya, urutan tertinggi dibawahnya adalah B80f1 (61.33 $\pm 1.26 \mathrm{mg} / \mathrm{L})$ dengan perbedaan nilai yang relatif kecil. Peningkatan kadar klorofil tersebut dikarenakan adanya suplai $\mathrm{N}$ dan fosfat.
\end{abstract}

Kata kunci : biofertilizer, kadar klorofil, sengon (Paraserianthes falcataria (L.) Nielsen).

\begin{abstract}
Chlorophyll is an important component needed in photosynthesis in which its formation is necessary for nutrients such as nitrogen and phosphate. Such nutrient supply may be assisted by the administration of biofertilizers containing nitrogen fixation bact eria, bacterial solvent phosphate and decomposer microbes. This study aims to determine the effect of dosage and frequency of biofertilizer administration on chlorophyll content of sengon seedlings (Paraserianthes falcataria (L.) Nielsen). The study consisted of 2 control treatments and 8 test treatments. Series of biofertilizer doses are $20,40,60$, and $80 \mathrm{~mL} /$ plant with the frequency of once a week and once every 2 weeks. Microbes in the biofertilizer consist of Azotobacter chroococum, Azospirillum brasilense, Rhizobium leguminosarum, Bacillus subtilis, B. megaterium, B. licheniformis, Pseudomonas fluorescens, P. putida, Cellvibrio mixtus, Cellulomonas cellulans, Cytophaga saccharophila, Lactobacillus plantarum, and Saccharomyces cerevisiae. This study used a complete randomized design (RAL) and the data were analyzed using one-way ANOVA test with continued test of Duncan test and Brown-Forsythe test with Gomes Howell's advanced test at $5 \%$ level. The results showed that the dosage and frequency of biofertilizer did not significantly affect the increase of leaf chlorophyll content. At $\mathrm{K}+\mathrm{f1}(65.28 \pm 1.07 \mathrm{mg} / \mathrm{L})$ showed the highest chlorophyll content and significantly influenced compared to others, the highest sequence was B80f1 (61.33 $\pm 1.26 \mathrm{mg} / \mathrm{L}$ ) with relatively small value difference. Increased levels of chlorophyll is due to the supply of $\mathrm{N}$ and phosphate.
\end{abstract}

Keywords: biofertilizer, chlorophyll content, sengon (Paraserianthes falcataria (L.) Nielsen).

\section{PENDAHULUAN}

Peningkatan kualitas tumbuhan dapat diupayakan dengan penggunaan mikroba tanah dalam membantu penyediaan nitrat, fosfat dan kalium serta unsur hara lainnya. Pupuk hayati semakin diperlukan karena pemakaian pupuk kimia selama ini mengakibatkan dampak yang kurang menguntungkan misalnya dapat menyebabkan pencemaran tanah sehingga tanah menjadi pekat, terjadi akumulasi $\mathrm{P}$, keadaan mikrobiologi tanah buruk, dan menurunkan $\mathrm{pH}$ tanah (Syaifudin dkk., 2010). Biofertilizer (pupuk hayati) berfungsi untuk membantu penyediaan hara bagi tanaman dan mempermudah penyerapan hara bagi tanaman yang sebagian besar unsur-unsur hara tersebut digunakan untuk proses fisiologis tanaman (Ermina, 2010). Selain itu juga membantu dekomposisi bahan organik dan menyediakan lingkungan rhizosfer yang lebih baik sehingga pada akhirnya akan mendukung pertumbuhan tanaman sehingga bisa disebut sebagai rhizobakteri (Sutedjo dkk., 1991). 
Menurut Meirina et al. (2011), penambahan unsur hara dari penambahan inokulan mikroba dapat meningkatkan unsur hara di dalam tanah. Pernyataan ini sesuai dengan pendapat Widawati dan Suliasih (2006) yang menyatakan bahwa pemberian inokulan bakteri sebagai pupuk hayati akan menaikkan populasi bakteri yang dapat melarutkan fosfat terikat dalam tanah dan menambat nitrogen dari udara. Populasi mikroba di dalam tanah dipengaruhi oleh beberapa faktor yaitu macam zat hara, nutrisi, $\mathrm{pH}$, dan suhu (Budiyanto, 2004). Hasil penelitian Yusran dkk. (2012) membuktikan bahwa pengaruh pemberian pupuk hayati yang menguntungkan dari jenis cendawan Trichoderma harzianum dan jenis bakteri Pseudomonas fluorescens, dan Bacillus sp. mampu meningkatkan pertumbuhan tinggi dan jumlah anak daun sengon. Bacillus sp. dan Pseudomonas sp. dilaporkan sebagai biofertilizer karena kelompok bakteri ini menghasilkan hormon tumbuh (Backman et al. 1994).

Klorofil termasuk faktor utama yang mempengaruhi fotosintesis. Fotosintesis merupakan proses perubahan senyawa anorganik (CO menjadi senyawa organik/karbohidrat) dan $\mathrm{O} 2$ dan $\mathrm{H}$ dengan bantuan cahaya matahari. Tiga fungsi utama klorofil dalam proses fotosintesis adalah memanfaatkan energi matahari, memicu fiksasi $\mathrm{CO} 2$ untuk menghasilkan karbohidrat dan menyediakan energi bagi ekosistem secara keseluruhan. Nitrogen merupakan unsur pokok pembentuk protein dan penyusun utama protoplas, kloroplas, dan enzim. Dalam kegiatan sehari-hari peran nitrogen berhubungan dengan proses fotosintesis dan respirasi (Suwahyono, 2011). Klorofil dapat dijadikan indikator yang sensitif pada kondisi fisiologis suatu tumbuhan karena kandungan klorofil berkorelasi positif dengan kandungan nitrogen daun, sehingga dapat dijadikan indikator laju fotosintesis (Sampson et al., 2003).

Berdasarkan uraian tersebut maka perlu dilakukan penelitian mengenai penggunaan konsorsium biofertilizer pada tanaman sengon (Paraserianthes falcataria (L.) Nielsen) terhadap kadar klorofil. Tujuan dari penelian ini adalah apakah dosis dan frekuensi pemberian biofertilizer yang berbeda berpengaruh terhadap kadar klorofil daun bibit sengon (Paraserianthes falcataria (L.) Nielsen). Diharapkan nantinya jika pemberian biofertilizer ini berdampak baik pada kadar klorofil maka juga akan meningkatkan laju fotosintesis.

\section{METODE}

\section{Bahan dan Alat penelitian}

Bahan yang digunakan dalam penelitian ini adalah bibit sengon (Paraserianthes falcataria (L.) Nielsen) umur 2 bulan dari Tani Sejahterah, Desa Tanjung Kalang, Prambon, Nganjuk. Selain itu media tanam yaitu tanah taman dan konsorsium mikroba yang terdiri dari 3 isolat mikroba penambat nitrogen, yaitu bakteri Azospirillum brasilense, Azotobacter chroococum, dan Rhizobium leguminosarum; 5 isolat mikroba pelarut fosfat, yaitu bakteri Bacillus licheniformis, B. subtilis, B. megaterium, Pseudomonas fluorescens, dan $P$. putida; dan 5 isolat mikroba pendegradasi bahan organik, yaitu Cellvibrio mixtus, Cellulomonas cellulans, Lactobacillus plantarum, Cytophaga saccharophila, dan khamir Saccharomyces cerevisiae. Media pertumbuhan yang digunakan untuk mikroba ini adalah NA (Nutrient Agar) (Oxoid), NB (Nutrient Broth) (Oxoid), PDA (Potato Dextrose Agar) (Oxoid), akuades, glukosa, molase $3 \%$, alkohol, spiritus, dan NPK (Phonska). Sedangkan media untuk menghitung jumlah populasi mikroba adalah MRS Agar, $\mathrm{Nfb}$ (Nitrogen-fixing bacteria yang terdiri atas asam malat 0,5 g; KOH 0,4 g; K2HPO4 0,05 g; FeSO4 0,005 g; $\mathrm{MnSO} 40,001 \mathrm{~g} ; \mathrm{MgSO}_{4} 0,01 \mathrm{~g} ; \mathrm{NaCl} 0,002 \mathrm{~g} ; \mathrm{CaCl} 2$ 0,002 g; Na2MoO2 0,001 g; bromotimol biru 0,5\% dalam alkohol $95 \%$ sebanyak $0,3 \mathrm{~mL}$, agar 0,175 g serta $100 \mathrm{~mL}$ akuades), media Pikovskaya (yang terdiri atas glukosa 0,1 g; Ca3PO4 0,5g; KCl 0,02 g; MgSO4 0,01 g; MnSO4 0,01 g; FeSO4 0,01 g; yeast extract 0,05 g; (NH4) $2 \mathrm{SO} 4$ 0,05 g; agar 0,12 g serta $100 \mathrm{~mL}$ akuades), CMC Agar (Carboxy Methyl Cellulose terdiri CMC $1 \mathrm{~g}, \mathrm{KNO} 3$ $0,075 \mathrm{~g}, \mathrm{MgSO} 4 \mathrm{H} 2 \mathrm{O}$ 0,02 g, KH2PO4 0,05 g FeSO47H2O $0,002 \mathrm{~g}, \mathrm{CaCl} 22 \mathrm{H} 2 \mathrm{O} 0,004 \mathrm{~g}$ dan Yeast $0,05 \mathrm{gr}$ serta 100 $\mathrm{mL}$ akuades).

Alat yang digunakan dalam penelitian ini antara lain autoclave (OSK 6500, ALP Co. Ltd), Laminar Air Flow (ESCO), shaker (GFL), spektrofotometer (Wilton Roy Company), timbangan analitik (Shimadzu), timbangan digital, colony counter (Galaxy 230), botol kaca (250 mL dan $500 \mathrm{~mL}$ ), labu Erlenmeyer (Pyrex), Petri dish, tabung reaksi (Pyrex), bunsen, jarum ose, pipet ukur (Pyrex), gelas ukur (Pyrex), gelas beaker (Duran), kertas label, aluminium foil, tisu, cling wrap, kapas, alat vortex, gelas obyek, cover glass, baskom, baki, kompor listrik, dan jerigen. Sedangkan alat yang digunakan di lahan pekarangan adalah polybag ukuran $15 \times 15 \mathrm{~cm}$, cangkul, meteran, penggaris, ember, dan kamera digital.

\section{Rancangan Penelitian}

Penelitian ini menggunakan metode eksperimental dengan Rancangan Acak Lengkap (RAL) dengan perlakuan variasi dosis dan frekuensi pemberian biofertilizer. Terdapat 11 macam perlakuan untuk pemberian biofertilizer yang menggunakan dosis $20,40,60$, dan 80 ( $\mathrm{mL} /$ tanaman) dengan frekuensi yang berbeda yaitu 1 kali dalam 1 minggu dan 1 kali dalam 2 minggu. Untuk kontrol berarti tanpa pemberian biofertilizer adalah kontrol negatif, sedangkan penambahan NPK $0.5 \mathrm{~g} /$ tanaman sebagai kontrol positif. Terdapat pengulangan sebanyak 4 kali setiap perlakuan. Dalam mempersingkat penyebutan maka akan digunakan singkatan sebagai berikut: K- : Tanpa pemberian biofertilizer, $\mathrm{K}+$ : Pupuk NPK $0.5 \mathrm{~g} /$ tanaman, B20 : Biofertilizer dengan dosis $20 \mathrm{~mL} /$ tanaman, B40 : Biofertilizer dengan dosis $40 \mathrm{~mL} /$ tanaman, B60 : Biofertilizer dengan dosis $60 \mathrm{~mL} /$ tanaman, B80 : 
Biofertilizer dengan dosis $80 \mathrm{~mL} /$ tanaman, f1 : Frekuensi pemberian 1 kali dalam 1 minggu, f2 : Frekuensi pemberian 1 kali dalam 2 minggu.

\section{Persiapan media, peremajaan isolat mikroba dan inokulasi mikroba}

Peremajaan isolat mikroba terlebih dahulu dilakukan dengan cara menyiapkan media NA slant agar untuk kelompok bakteri dan media PDA slant agar untuk kelompok fungi dalam tabung reaksi. Pembuatan media NA dilakukan dengan melarutkan 2,8 g NA ke dalam akuades hingga bervolume $100 \mathrm{~mL}$. Untuk media PDA sebanyak 3,9 g dilarutkan ke dalam akuades hingga bervolume $100 \mathrm{~mL}$. Peremajaan isolat mikroba ke media slant agar dilakukan dengan cara satu ose biakan mikroba dari kultur murni ditanam dengan metode streak ke dalam media slant agar

Media NB + glukosa $1 \%$ dibuat dengan komposisi, 3,25 g NB dan 2,5 g glukosa dilarutkan ke dalam akuades $250 \mathrm{~mL}$ pada gelas beaker. Setelah itu, larutan media tersebut dimasukkan kedalam botol bervolume $500 \mathrm{~mL}$ lalu ditutup dengan kapas dan aluminium foil dan disterilkan selama 15 menit. Setelah media NB steril, langkah selanjutnya adalah dilakukan inokulasi mikroba dari media slant agar ke media broth $250 \mathrm{~mL}$ pada suhu ruang sambil dishaker.

\section{Penentuan jumlah koloni mikroba dengan metode turbiditas dan TPC (Total Plate Count)}

Tabung reaksi yang berisi akuades steril (tiap tabung berisi $9 \mathrm{~mL}$ ) disterilkan dalam autoclave selama 15 menit. Untuk mengetahui turbiditasnya maka dilakukan dengan menghitung nilai OD dari kultur murni dengan menggunakan spektrofotometer. Terlebih dahulu ditetapkan nilai OD awal dengan blanko NB. Kemudian $5 \mathrm{~mL}$ dari masing-masing inokulum mikroba $250 \mathrm{~mL}$ dimasukkan ke dalam tabung kuvet untuk diukur absorbansinya dengan spektrofotometer pada $\lambda$ $=600 \mathrm{~nm}$. Dari inokulum mikroba $250 \mathrm{~mL}$ tersebut, kemudian dilakukan seri pengenceran hingga $10^{9}$. Seri pengenceran dilakukan dengan cara $1 \mathrm{~mL}$ mikroba dari inokulum mikroba $250 \mathrm{~mL}$ dimasukkan ke dalam tabung reaksi berisi akuades $9 \mathrm{~mL}$ berlabel $10^{-1}$ lalu dihomogenkan dengan menggunakan alat vortex selama 1 menit. Begitu seterusnya hingga pengenceran ke-9. Pada pengenceran ke-6, 7, dan 8 diambil $1 \mathrm{~mL}$ kemudian dimasukkan kedalam cawan petri. Setelah itu, menuangkan media selektif sesuai peran mikroba sebanyak $15 \mathrm{~mL}$. Untuk bakteri Lactobacillus plantarum menggunakan media MRS Agar, mikroba pelarut fosfat adalah Pikovskaya dan mikroba pendegradasi bahan organik adalah media agar CMC. Setelah itu, dihomogenkan dengan cara memutar cawan Petri dengan bentuk putaran membentuk angka delapan dan dibiarkan hingga memadat. Lalu cawan Petri diisolasi dengan menggunakan cling wrap dan diinkubasi pada suhu 37C selama 1 kali 24 jam. Selanjutnya, jumlah koloni bakteri dihitung dengan metode Total Plate
Count (TPC) dengan menggunakan colony counter. Menurut Nersser (1895), jumlah koloni yang diambil harus berkisar antara 30 - 300 koloni (Anonim, 2014). Setelah itu, dikalikan dengan seper faktor pengenceran dan satuan jumlah koloni yang digunakan adalah $\mathrm{CFU} / \mathrm{mL}$.

\section{Penghitungan MPN (Most Probable Number)}

Metode MPN ini digunakan untuk perhitungan bakteri kelompok penambat nitrogen. Menyiapkan botol pengenceran $250 \mathrm{~mL}$ yang berisikan akuades 90 $\mathrm{mL}$ dan tabung reaksi yang berisikan media $\mathrm{Nfb}$, lalu disterilisasi dalam autoclave selama 15 menit. Kemudian dari inokulum mikroba $250 \mathrm{~mL}$ tersebut, dilakukan seri pengenceran hingga $10^{-9}$. Metode pengenceran dilakukan dengan cara $10 \mathrm{~mL}$ mikroba dari inokulum mikroba $250 \mathrm{~mL}$ dimasukkan ke dalam botol kaca yang berisi akuades $90 \mathrm{~mL}$ berlabel $10^{-1}$ lalu dihomogenkan dengan menggunakan alat vortex selama 1 menit. Begitu seterusnya hingga pengenceran ke-9. Metode MPN menggunakan tabung seri 3-3-3. Pada hasil pengenceran ke-6, diambil $10 \mathrm{~mL}, 1 \mathrm{~mL}$, dan $0,1 \mathrm{~mL}$ pada setiap tabung seri. Kemudian diisolasi dengan menggunakan cling wrap dan mengiinkubasi pada suhu ruang sekitar $5 \times 24$ jam.

\section{Pembuatan starter pupuk hayati (biofertilizer) dan perhitungan kuantitas mikroba}

Pembuatan starter terlebih dahulu menyiapkan larutan molase 3\% untuk setiap mikroba dengan cara molase $6 \mathrm{~mL}$ dilarutkan ke dalam akuades hingga volume menjadi $200 \mathrm{~mL}$. Larutan molase yang telah jadi dimasukkan ke dalam botol bervolume 500 $\mathrm{mL}$, kemudian disterilkan dalam autoclave selama 15 menit dengan tekanan $1 \mathrm{~atm}$. Setelah itu, dibiarkan hingga dingin pada suhu ruang. Lalu dari inokulum mikroba $200 \mathrm{~mL}$ (F2) dicampur dengan larutan molase $3 \%$ sebanyak $200 \mathrm{~mL}$ sehingga volume total starter menjadi $400 \mathrm{~mL}$ (F340). Dari semua inokulum mikroba $400 \mathrm{~mL}$ (F3) tersebut dicampur ke dalam jirigen menjadi $5200 \mathrm{~mL}$ dan ditambahkan media molase 3\% sebanyak $9800 \mathrm{~mL}$ (aquades $9506 \mathrm{~mL}$, molase $294 \mathrm{~mL}$ ) hingga totalnya menjadi $15000 \mathrm{~mL}$ kemudian dihomogenkan dan didiamkan selama 5 hari (F4). Setelah di homogenkan, biofertilizer dibuat dalam beberapa konsentrasi yaitu: 20, 40,60, dan $80 \mathrm{~mL} /$ tanaman

Terlebih dahulu dilakukan perhitungan menggunakan metode TPC dengan media selektif, sebelum biofertlizer diaplikasikan langsung pada tanaman. Penggunaan media selektif ini berfungsi untuk menumbuhkan ketiga kelompok mikroba yaitu dengan mencawankan pengenceran ke 6, 7,8 ke media CMC Agar untuk kelompok mikroba pendegradasi bahan organik, dan media Pikovskaya untuk kelompok bakteri pelarut fosfat. Lalu untuk mikroba pemfiksasi nitrogen dihitung dengan metode Most Probable Number (MPN) menggunakan media Nfb. Jumlah sel bakteri penambat nitrogen dapat dicocokkan dengan 
tabel Mc. Grady. Adanya bakteri penambat nitrogen ditunjukkan dengan terbentuknya folikel atau selaput putih. Selain itu terjadi perubahan warna menjadi biru yang menunjukkan bahwa adanya aktivitas nitrogenase.

\section{Analisis tanah}

Sebelum tanah diletakkan di dalam polybag, terlebih dahulu penghitungan populasi mikroba tanah menggunakan metode TPC dan MPN pada media selektif. Media selektif digunakan untuk untuk menumbuhkan ketiga kelompok mikroba, yaitu mikroba penambat nitrogen, mikroba pelarut fosfat, dan mikroba dekomposer. Metode penghitungan ini dilakukan dengan cara mencawankan pengenceran ke3, 4, dan 5 ke dalam media agar CMC, Pikovskaya dan mikroba penambat nitrogen dengan menggunakan media Nfb dihitung dengan metode MPN (Most Probable Number) dengan cara mengambil sampel pada pengenceran ke-1 lalu dimasukkan ke media $\mathrm{Nfb}$ semisolid pada tabung reaksi. Jumlah tabung positif disesuaikan dengan tabel McCrady. Tabung positif ditandai dengan terbentuknya pelikel putih dan warna biru pada permukaan media. Populasi mikroba ditentukan dalam satuan MPN/100 mL suspensi. Dan analisi tanah juga ini dilakukan setelah perlakuan.

\section{Perlakuan tanaman}

Sebelum perlakuan, dilakukan persiapan media tanam dengan cara memindahkan bibit tanaman sengon ke polybag yang berukuran $15 \times 15 \mathrm{~cm}$ yang telah berisi tanah taman seberat $4 \mathrm{~kg} /$ polybag. Pemberian biofertilizer 20, 40, 60, dan $80 \mathrm{~mL} /$ tanaman dengan waktu frekuensi 1 kali dalam 1 minggu diberikan pada perlakuan ke-3, 4, 5, dan 6. Sedangkan untuk frekuensi 1 kali dalam 2 minggu diberikan pada perlakuan ke-8, 9, 10, dan 11. Tiap perlakuan memiliki 4 kali pengulangan.

\section{Perhitungan kadar klorofil daun}

Perhitungan kadar klorofil dengan menggunakan spektrofotometer dilakukan setiap 4 minggu sekali. Daun yang diambil adalah daun nomor 3 dari bawah (Hendriyani dkk, 2009). Menimbang $1 \mathrm{~g}$ dan digerus dalam mortar dengan pelarut alkohol 95\% sebanyak $20 \mathrm{ml}$. Alkohol 95\% berfungsi untuk melarutkan klorofil. Setelah klorofil larut dalam alkohol 95\% disentrifugasi selama 10 menit dengan kecepatan 500 rpm. Dalam spektrofotometer ini terdapat 2 tabung cuvet, tabung cuvet 1 berisi alkohol 95\% sebagai blanko dan tabung cuvet 2 berisi ekstrak klorofil. Absorbansi larutan ekstrak klorofil ini menggunakan panjang gelombang $649 \mathrm{~nm}$ dan $665 \mathrm{~nm}$ (Purnobasuki, 2012). Setelah kadar klorofil diketahui, selanjutnya dapat dihitung kadar klorofil total dengan menggunakan turunan rumus (Winstermans dan Mots, 1965 dalam Purnobasuki, 2012).

\section{Analisis Data}

Data yang telah didapatkan dari pertumbuhan tanaman sengon kemudian ditampilkan dalam bentuk tabel pengumpulan data. Data statistik yang diperoleh dalam penelitian ini kemudian dianalisis dengan menggunakan SPSS (Statistical Product and Service Solution). Uji yang dilakukan uji adalah KolmogrovSmirnov untuk mengetahui normalitas data, kemudian uji Levene test untuk mengetahui homogenitas data. Jika data berdistribusi normal dan homogen maka diuji dengan menggunakan ANAVA (Analisis Varian) satu arah (One Way Anova) dengan derajat signifikan 5\%. Bila data normal dan homogen memiliki pengaruh nyata maka dilanjutkan dengan uji DMRT (Duncan's Multiple Range Test) untuk membandingkan antar perlakuan. Bila data normal dan tidak homogen maka diuji dengan uji Games-Howell. Bila data tidak normal dan tidak homogen maka diuji dengan menggunakan uji KruskalWallis dan jika berpengaruh maka dilanjutkan dengan uji Mann-Whitney.

Klorofil total $(\mathrm{mg} / \mathrm{L})=(20,0 \times$ OD649 $)+(6,1 \times$ OD665 $)$

\section{HASIL DAN PEMBAHASAN}

\section{Hasil analisis jumlah total mikroba biofertilizer dan mikroba tanah}

Penghitungan jumlah total tiap mikroba biofertilizer dan mikroba tanah dilakukan dengan metode TPC dan MPN. Berikut ini (tabel.1) merupakan jumlah total tiap mikroba, mikroba tanah sebelum perlakuan (tabel.2), dan mikroba tanah polybag setelah perlakuan (tabel.3).

Tabel 1. Jumlah total mikroba biofertilizer

\begin{tabular}{|c|c|c|c|c|c|}
\hline No. & Species mikroba & Jenis media & $\begin{array}{c}\text { Nilai } \\
\text { absorbansi } \\
\text { pada } \lambda= \\
600 \mathrm{~nm}\end{array}$ & $\begin{array}{c}\text { Jumlah } \\
\text { total } \\
\text { mikroba } \\
\text { (CFU/mL) }\end{array}$ & $\begin{array}{l}\text { Jumlah total } \\
\text { mikroba } \\
\text { (MPN/100mL) }\end{array}$ \\
\hline 1. & Bacillus subtilis & Pikovskaya & 1 & $1.9 \times 10^{11}$ & \\
\hline 2. & B. megaterium & Pikovskaya & 1 & $8.1 \times 10^{10}$ & \\
\hline 3. & B. licheniformis & Pikovskaya & 1 & $5.4 \times 10^{10}$ & \\
\hline 4. & $\begin{array}{l}\text { Pseudomonas } \\
\text { fluorescens }\end{array}$ & Pikovskaya & 0.9 & $6.6 \times 10^{9}$ & \\
\hline 5. & P. putida & Pikovskaya & 1 & $2.2 \times 10^{10}$ & \\
\hline 6. & Cellvibrio mixtus & $\mathrm{CMC}$ & 1 & $3.8 \times 10^{10}$ & \\
\hline 7. & $\begin{array}{l}\text { Cellulomonas } \\
\text { cellulans }\end{array}$ & $\mathrm{CMC}$ & 1 & $2.1 \times 10^{9}$ & \\
\hline 8. & $\begin{array}{c}\text { Cythophaga } \\
\text { saccharophila }\end{array}$ & $\mathrm{CMC}$ & 1 & $1.6 \times 10^{8}$ & \\
\hline 9. & $\begin{array}{l}\text { Lactobacillum } \\
\text { plantarum }\end{array}$ & MRSA & 1 & $3.5 \times 10^{11}$ & \\
\hline 10. & $\begin{array}{c}\text { Saccharomyces } \\
\text { cerevisiae }\end{array}$ & PDA & 1 & $3.4 \times 10^{10}$ & \\
\hline 11. & $\begin{array}{l}\text { Azotobacter } \\
\text { chroococum }\end{array}$ & $\mathrm{Nfb}$ & 1 & & $1.5 \times 10^{7}$ \\
\hline 12. & $\begin{array}{l}\text { Azospirillum } \\
\text { brasilense }\end{array}$ & $\mathrm{Nfb}$ & 0.8 & & $1.4 \times 10^{7}$ \\
\hline 13. & $\begin{array}{c}\text { Rhizobium } \\
\text { leguminosarum }\end{array}$ & $\mathrm{Nfb}$ & 1 & & $2.0 \times 10^{7}$ \\
\hline
\end{tabular}


Tabel 2. Jumlah total mikroba tanah sebelum perlakuan

\begin{tabular}{|c|c|c|c|}
\hline \multirow{3}{*}{ Sampel } & \multicolumn{3}{|c|}{ Jumlah total mikroba fungsional } \\
\cline { 2 - 4 } & $\begin{array}{c}\text { Mikroba } \\
\text { dekomposer pada } \\
\text { media agar CMC } \\
(\mathrm{CFU} / \mathrm{mL})\end{array}$ & $\begin{array}{c}\text { Mikroba pelarut } \\
\text { posfat pada media } \\
\text { agar Pikovskaya } \\
(\mathrm{CFU} / \mathrm{mL})\end{array}$ & $\begin{array}{c}\text { Mikroba } \\
\text { penambat } \\
\text { nitrogen pada } \\
\text { media Nfb } \\
\text { semisolid } \\
(\mathrm{MPN} / 100 \mathrm{~mL})\end{array}$ \\
\hline Tanah polybag & $2.4 \times 10^{4}$ & $3.4 \times 10^{5}$ & $7 \times 10^{3}$ \\
\hline
\end{tabular}

Tabel 3. Jumlah total mikroba tanah setelah perlakuan

\begin{tabular}{|c|c|c|c|}
\hline \multirow[b]{2}{*}{$\begin{array}{c}\text { Sampel tanah } \\
\text { polybag }\end{array}$} & \multicolumn{3}{|c|}{ Jumlah total mikroba fungsional } \\
\hline & $\begin{array}{c}\text { Mikroba } \\
\text { dekomposer pada } \\
\text { media agar CMC } \\
(\mathrm{CFU} / \mathrm{mL})\end{array}$ & $\begin{array}{c}\text { Mikroba pelarut } \\
\text { posfat padamedia } \\
\text { agar Pikovskaya } \\
(\mathrm{CFU} / \mathrm{mL})\end{array}$ & $\begin{array}{c}\text { Mikroba penambat } \\
\text { nitrogen pada media } \\
\mathrm{Nfb} \text { semisolid } \\
(\mathrm{MPN} / 100 \mathrm{~mL})\end{array}$ \\
\hline K-fl & $1.0 \times 10^{4}$ & $2.8 \times 10^{4}$ & $3.0 \times 10^{3}$ \\
\hline $\mathrm{K}+\mathrm{fl}$ & $1.5 \times 10^{4}$ & $1.2 \times 10^{4}$ & $3.0 \times 10^{3}$ \\
\hline B20f1 & $6.2 \times 10^{5}$ & $8.2 \times 10^{6}$ & $2.1 \times 10^{4}$ \\
\hline B40fl & $8.9 \times 10^{5}$ & $7.9 \times 10^{5}$ & $2.8 \times 10^{4}$ \\
\hline B60fl & $5.5 \times 10^{7}$ & $4.4 \times 10^{7}$ & $2.8 \times 10^{4}$ \\
\hline B80fl & $2.2 \times 10^{7}$ & $1.2 \times 10^{7}$ & $2.8 \times 10^{4}$ \\
\hline $\mathrm{K}+\mathrm{f} 2$ & $2.2 \times 10^{4}$ & $1.6 \times 10^{4}$ & $4.0 \times 10^{3}$ \\
\hline $\mathrm{B} 20 \mathrm{f} 2$ & $4.4 \times 10^{4}$ & $6.4 \times 10^{4}$ & $1.5 \times 10^{4}$ \\
\hline B40f2 & $7.1 \times 10^{5}$ & $9.1 \times 10^{5}$ & $2.0 \times 10^{4}$ \\
\hline B60f2 & $1.8 \times 10^{5}$ & $7.8 \times 10^{5}$ & $2.0 \times 10^{4}$ \\
\hline B80f2 & $3.1 \times 10^{5}$ & $3.9 \times 10^{5}$ & $2.8 \times 10^{4}$ \\
\hline
\end{tabular}

Keterangan : $\mathrm{K}-$ : tanpa pupuk apapun; $\mathrm{K}+$ : pemberian pupuk NPK (0.5 g/tanaman); B20, B40, B60, B80 : perlakuan biofertilizer $20,40,60$, dan $80 \mathrm{ml} /$ tanaman; $\mathrm{f} 1$ : pemberian $1 \times 1$ minggu; $\mathrm{f} 2$ : pemberian $1 \times 2$ minggu.

Hasil yang ditunjukkan tabel.1 tersebut menunjukkan bahwa jumlah total mikroba fungsional telah memenuhi standar baku mutu biofertilizer berdasarkan peraturan menteri pertanian melalui metode penghitungan TPC dan MPN dengan jumlah total mikroba terendah mencapai $1.6 \times 10^{8} \mathrm{CFU} / \mathrm{mL}$ pada bakteri Cythophaga saccharophila, sedangkan jumlah tertinggi mencapai $1.9 \times 10^{11} \mathrm{CFU} / \mathrm{mL}$ pada bakteri Bacillus subtilis. Sehingga formulasi konsorsium mikroba dapat diaplikasikan ke tanaman sebagai biofertilizer. Jumlah total mikroba fungsional setelah perlakuan (tabel.3) lebih tinggi dibandingkan sebelumnya. Hal ini ditunjukkan dengan tabel.2, jumlah total mikroba dekomposer sebelum perlakuan yaitu 2.4 $x 10^{4} \mathrm{CFU} / \mathrm{mL}$, mikroba pelarut fosfat dan mikroba pemfiksasi nitrogen berturut-turut adalah $3.4 \times 10^{4}$ serta $7 \times 10^{3} \mathrm{MPN} / 100 \mathrm{~mL}$. Jumlah ini lebih rendah dibandingkan dengan jumlah total mikroba tanah setelah perlakuan yang dapat mencapai $5.5 \times 10^{7}$ $\mathrm{CFU} / \mathrm{mL}$ pada mikroba dekomposer. Hal yang sama juga diperlihatkan pada mikroba pelarut fosfat maupun mikroba penambat nitrogen $4.4 \times 10^{7} \mathrm{MPN} / 100 \mathrm{~mL}$ serta $2.8 \times 10^{4} \mathrm{MPN} / 100 \mathrm{~mL}$ pada media semisolid $\mathrm{Nfb}$ (tabel.3).
Tabel 4. Rata-rata kadar klorofil daun tanaman sengon tiap perlakuan

\begin{tabular}{|l|l|}
\hline Perlakuan & Kadar klorofil (m/L) \\
\hline K- & $54,16 \pm 1,14^{\mathrm{a}}$ \\
\hline K+f1 & $65,28 \pm 1,07^{\mathrm{c}}$ \\
\hline B20f1 & $52,48 \pm 0,81^{\mathrm{a}}$ \\
\hline B40f1 & $57,64 \pm 0.52^{\mathrm{a}}$ \\
\hline B60f1 & $60,3 \pm 0,53^{\mathrm{b}}$ \\
\hline B80f1 & $61,33 \pm 1,26^{\mathrm{b}}$ \\
\hline K+f2 & $51,33 \pm 1,35^{\mathrm{a}}$ \\
\hline B20f2 & $53,43 \pm 0,45^{\mathrm{a}}$ \\
\hline B40f2 & $54,53 \pm 0,59^{\mathrm{a}}$ \\
\hline B60f2 & $54,94 \pm 172^{\mathrm{ab}}$ \\
\hline B80f2 & $57,7 \pm 2^{\text {ab }}$ \\
\hline
\end{tabular}

Keterangan : K- : tanpa pupuk apapun; $\mathrm{K}+$ : pemberian pupuk NPK (0.5g/tanaman); B20, B40, B60, B80 : perlakuan biofertilizer 20, 40, 60, dan $80 \mathrm{ml} /$ tanaman; f1 : pemberian 1x1 minggu; f2 : pemberian 1x2 minggu

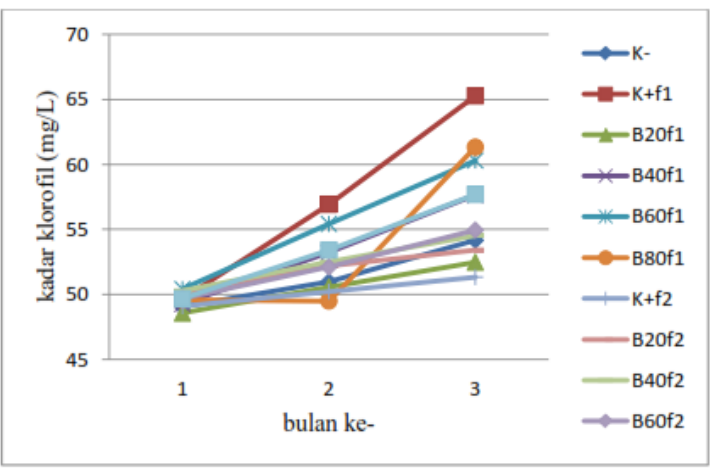

Gambar 1. Kadar klorofil daun tanaman sengon pada berbagai perlakuan

setelah bulan ke-1, 2, dan 3. Keterangan : K- : tanpa pupuk apapun; $\mathrm{K}+$ : pemberian pupuk NPK

(5g/tanaman); B20, B40, B60, B80 : perlakuan biofertilizer 20, 40,60, dan $80 \mathrm{ml} /$ tanaman; f1 : pemberian 1x1 minggu; f2 :pemberian 1x2 minggu.

Perhitungan parameter kadar klorofil daun tanaman sengon dilakukan pada bulan ke-1, 2, dan 3 setelah perlakuan. Hal ini dikarenakan adanya keterbatasan jumlah daun pada setiap tanaman. Daun yang dihitung adalah yang memiliki posisi nomor 3 dari bawah dengan ketentuan daun dalam keadaan daun segar, berwarna hijau, dan tidak rontok. Hasil perhitungan kadar klorofil daun dapat dilihat pada tabel.4 dan gambar.1. Grafik kadar klorofil daun tanaman sengon pada gambar.1 menunjukkan bahwa laju pertambahan dari bulan pertama hingga bulan ke3 relatif konstan. Namun, kadar klorofil tertinggi dicapai $\mathrm{K}+\mathrm{f} 1$ pada bulan ke-2 dan ke-3 yaitu $56.49 \mathrm{mg} / \mathrm{L}$ dan 
$65.28 \mathrm{mg} / \mathrm{L}$, kemudian disusul oleh B80f1 yaitu 61.32 $\mathrm{mg} / \mathrm{L}$ pada bulan terakhir. Sedangkan kadar klorofil terendah diraih $\mathrm{K}+\mathrm{f} 2$ dengan

nilai $51.33 \mathrm{mg} / \mathrm{L}$.

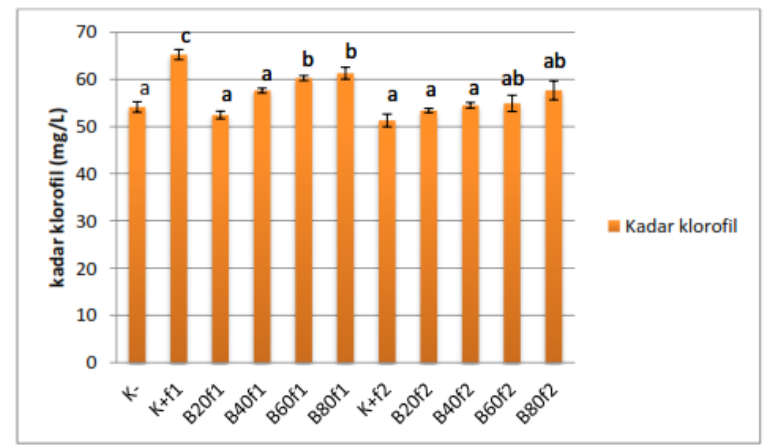

Gambar 2. Rata-rata kadar klorofil daun sengon pada berbagai perlakuan pada minggu ke-12

Berdasarkan uji normalitas dengan uji Kolmogorov-Smirnov dan uji homogenitas dengan uji Levene menunjukkan bahwa kadar klorofil berdistribusi secara normal namun data tidak homogen pada taraf 5\%. Uji ANAVA satu arah terhadap parameter kadar klorofil daun menunjukkan hasil yang berpengaruh signifikan $(P(0,000)<a(0,05))$ oleh perlakuan yang diberikan. Oleh karena data yang dihasilkan tidak homogen, maka dilanjutkan dengan uji Brown-Forsythe. Hasil uji menunjukkan bahwa kadar klorofil daun berpengaruh nyata oleh perlakuan yang diberikan ( $P$ $(0,000)<$ a $(0,05))$, namun pada hasil pada perlakuan tidak lebih baik daripada kontrol.

Nilai rerata tertinggi dicapai oleh $\mathrm{K}+\mathrm{f} 1$ yaitu pemberian pupuk NPK $0.5 \mathrm{gr} /$ tanaman dengan frekuensi pemberian sekali dalam satu minggu. Pada gambar. 2 menunjukkan bahwa K+f1 (65.28 \pm 1.07 mg/L) menunjukkan kadar klorofil tertinggi dan berpengaruh secara signifikan dibanding dengan lainnya. Hasil tertinggi dibawahnya adalah B80f1 (61.33 $\pm 1.26 \mathrm{mg} / \mathrm{L})$ dengan perbedaan nilai yang relatif kecil. Djukri dan Bambang (2003) menyatakan bahwa adanya penurunan kadar nitrogen pada tanaman berpengaruh terhadap fotosintesis, baik lewat kandungan klorofil maupun enzim fotosintetik. Hal ini terlihat pada perlakuan $\mathrm{K}$ - (54.16 $\pm 1.11 \mathrm{mg} / \mathrm{L})$ yang merupakan hasil terendah pada parameter kadar klorofil. Perlakuan Ktidak berbeda signifikan terhadap B20f1 (52.49 \pm 0.81 $\mathrm{mg} / \mathrm{L})$, B40f1 (57.64 $\pm 0.50 \mathrm{mg} / \mathrm{L}), \mathrm{K}+\mathrm{f} 2(51.33 \pm 1.35$ $\mathrm{mg} / \mathrm{L})$, B20f2 (53.43 $\pm 0.45 \mathrm{mg} / \mathrm{L})$, B40f2 (54.53 \pm 0.59 $\mathrm{mg} / \mathrm{L})$, B60f2 (54.94 $\pm 1.72 \mathrm{mg} / \mathrm{L})$, serta B80f2 (57.7 \pm $2.00 \mathrm{mg} / \mathrm{L})$.

Klorofil merupakan komponen kloroplas yang utama dan kandungan klorofil berkorelasi positif dengan laju fotosintesis (Danks et al., 1983). Hal tersebut yang mendasari penelitian ini untuk mengetahui adanya pengaruh dosis biofertilizer terhadap kadar klorofil dimana menjadi gagasan dapat menambah hasil fotosintesisnya. Klorofil disintesis di daun dan berperan untuk menangkap cahaya matahari yang jumlahnya berbeda untuk tiap spesies. Sintesis klorofil dipengaruhi oleh berbagai faktor seperti cahaya, gula atau karbohidrat, air, temperatur, faktor genetik, unsur-unsur hara seperti $\mathrm{N}, \mathrm{Mg}, \mathrm{Fe}, \mathrm{Mn}, \mathrm{Cu}, \mathrm{Zn}, \mathrm{S}$ dan $\mathrm{O}$ (Hendriyani dan Setiari, 2009). Adanya peranan mikroba yang mampu menambat $\mathrm{N}$, melarutkan $\mathrm{P}$, dan merombak bahan organik dalam biofertilizer dapat menyediakan kebutuhan unsur hara seperti $\mathrm{N}, \mathrm{P}$, dan $\mathrm{K}$ serta unsur hara lainnya yang kemudian akan diserap oleh tanaman untuk selanjutnya digunakan dalam proses metabolisme. Suplai hara yang cukup membantu terjadinya proses fotosintesis dan menghasilkan senyawa organik yang akan diubah dalam bentuk ATP saat berlangsungnya respirasi, selanjutnya ATP ini akan digunakan untuk membantu pertumbuhan tanaman (Meirina et al., 2011). Tanaman yang mendapat cukup hara dapat menyelesaikan siklus hidupnya lebih cepat, sedangkan tanaman yang kekurangan hara akan berpengaruh pada proses pertumbuhan dan perkembangan sehingga berjalan lebih lambat (Rasyid et al., 2010).

Berdasarkan hasil bahwa dosis dan frekuensi dari biofertilizer berpengaruh nyata terhadap kadar klorofil yaitu pada perlakuan kontrol positif dengan frekuensi pemberian seminggu sekali, hal ini karena adanya pemenuhan unsur-unsur penting oleh pupuk NPK. Pada perlakuan B80f1 (61.33 $\pm 1.26 \mathrm{mg} / \mathrm{L})$ juga menunjukkan kadar klorofil yang tinggi, hal ini dikarenakan adanya pemenuhan unsur penyusun klorofil. Unsur-unsur tersebut dipenuhi karenan adanya peranan dari mikroba dalam biofertilizer. Unsur hara $\mathrm{N}$ dan $P$ berguna untuk pembentukan klorofil dan kloroplas pada daun yang nantinya berguna untuk proses fotosintesis. Gardner et al (1991) mengemukakan bahwa daun dibutuhkan untuk penyerapan dan pengubahan energi cahaya matahari menjadi zat-zat yang dibutuhkan untuk pertumbuhan melalui fotosintesis. Dari hasil dapat dilihat bahwa mikroba dalam biofertilizer berpengaruh terhadap peningkatan kadar klorofil namun belum dapat berfungsi maksimal, masih perlu adanya penelitian lebih lanjut tentang komposisi biofertilizer yanag tepat dan dapat dikombinasikan dengan pupuk. Pemilihan bakteri pada penelitian kali ini sudah tepat seperti Azotobacter sp. yang merupakan mikroba untuk memfiksasi nitrogen bebas dan tidak bersimbiosis dengan tanaman. Dengan bantuan enzim azotase, Azotobacter sp. mengkonversi dinitrogen menjadi ammonium melalui reduksi elektron dan protonasi gas dinitrogen (Hendarsah dan Simarmata, 2004). Molekul nitrogen bebas diubah menjadi nitrogen sel. Nitrogen yang terikat pada struktur tubuh bakteri ini dilepas dalam bentuk organik sebagai sekresi atau setelah Azotobacter sp. itu mati (Isminarni $d k k$, 2007).

Mikroba lain yaitu mikroba perombak bahan organik Cellulomonas sp., Lactobacillus plantarum dan 
Saccharomyces cereviceae dapat menyediakan unsur $\mathrm{N}$ $\mathrm{P}$ dan K. Mikroba perombak bahan organik ini banyak digunakan untuk mempercepat proses dekomposisi sisa-sisa tanaman yang banyak mengandung lignin dan selulosa untuk meningkatkan kandungan bahan organik dalam media tanam (Rosmarkam dan Nasih, 2002). Pada dosis yang lain peningkatan kadar klorofil memang tidak begitu signifikan, hal ini dapat dikarenakan mikroba penambat $\mathrm{N}$ yang kurang berfungsi optimal.

\section{SIMPULAN}

Dosis dan frekuensi pemberian biofertilizer berpengaruh nyata terhadap kadar klorofil daun bibit sengon (Paraserianthes falcataria (L.) Nielsen) yaitu oleh perlakuan $\mathrm{K}+\mathrm{f} 1$ dengan nilai mencapai $65.28 \pm 1.07$ $\mathrm{mg} / \mathrm{L}$. Hasil dari pemberian berbagai dosis dan frekuensi tidak lebih bagus jika dibandingkan dengan kontrol $(\mathrm{K}+\mathrm{f} 1)$, urutan hasil tertinggi dibawah kontrol adalah B80f1 $(61.33 \pm 1.26 \mathrm{mg} / \mathrm{L})$ dengan perbedaan nilai yang relatif kecil. Peningkatan kadar klorofil tersebut dikarenakan adanya suplai $\mathrm{N}$ dan fosfat.

\section{DAFTAR PUSTAKA}

Backman PA, Brannnen PM and Mahaffe WF.1994. Plant Respon and Disease Control Followin Seed Inoculation with Bacillus sp. Di dalam: Ryder MH,Stephen PM, Bowen GD, editor. Improving Plant Production withRhizosphere Bacteria. Australia: Pruc Third Int Work PGPR South Australia, March 7-11 1994.

Budiyanto, M. A. K. 2004. Mikrobiologi Terapan. Universitas Muhammadiyah Press. Malang.

Danks SM, Evans, Whittaker PA (1983). Photosyinthetic system. John Willey \&Sons, New York

Ermina, Y. 2010. Media Tanaman Hidroponik dari Arang Sekam. Balai BesarPelatihan.

Gardner, F. P., R. B. Pearce, dan R.L. Mitchell. 1991. Fisiologi Tanaman Budidaya. Jakarta : UI Press.

Hendriyani, Ika Susanti dan Setiari, Nintya. 2009. Kandungan Klorofil dan Pertumbuhan Kacang Panjang (Vigna sinensis) pada Tingkat Penyediaan Air yang Berbeda. J. Sains \& Mat. Vol 17 No. 3, Juli 2009: 145-150.

Hindersah, R dan Simarta, Tualar. 2004. Potensi Rizobakteri Azotobacter dalam Meningkatkan Kesehatan Tanah. Fakultas Pertanian Padjajaran. Bandung.
Isminarni, F., S. Wedhastri, J. Widada, B.H. Purwanto, 2007, Penambat nitrogen dan penghasilan indol asam aetat oleh isolat-isolat Azotobacter pada $\mathrm{pH}$ rendah dan aluminium tinggi, Jurnal IImu Tanah dan Lingkungan, 7(1): 23-30.

Meirina, T., Darmanti, S., dan Haryanti, S., 2011, Produktivitas Kedelai (Glycine max (L) Merril var. lokon) yang diperlakukan dengan Pupuk Organik Cair Lengkap pada Dosis dan Waktu Pemupukan yang Berbeda, Skripsi, Jurusan Biologi MIPA, Universitas Diponegoro, Semarang.

Purnobasuki, H., 2012, Panduan Praktikum Fisiologi Tumbuhan, Departemen Biologi, Fakultas Sains dan Teknologi, Universitas Airlangga, Surabaya.

Rasyid, B., Samosir, S. S. R., dan Sutomo, F., 2010, Respon tanaman jagung (Zea mays) pada berbagai regim air tanah dan pemberian pupuk nitrogen, Prosiding Pekan Serealia Nasional: 26-34.

Rosmarkam, A.,dan Nasih Y., 2002,IImu Kesuburan Tanah, Kanisius, Yogyakarta.

Sampson, P.H., Zarco, T.P., Mohammed, G.H., Miller, J.R., and Noland, T., 2003, Hyperspectral remote sensing of forest condition: estimatingchlorophyll content in tolerant hardwoods, Forest Science 49 (3): 381-391.

Sutedjo, M.M., A.G. Kartasapoetra, dan Sastroatmodjo, S. 1991. Mikrobiologi Tanah. Rineka Cipta, Jakarta.

Suwahyono, U., 2011, Petunjuk Praktis Penggunaan Pupuk Organik Secara Efektif dan Efisien. Penebar Swadaya, Jakarta

Syaifudin, A., L. Mulyani, M. Ariesta. 2010. Pupuk Kosarmas Sebagai Upaya Revitalisas Lahan Kritis Guna Meningkatkan Kualitas dan Kuantitas Hasil Pertanian. Skripsi. UNS

Widawati, S dan Suliasih, 2006, Augmentasi bakteri pelarut fosfat (BPF) potensial sebagai pemacu pertumbuhan caysin (Brasica caventis oed) di tanahmarginal, Jurnal Biodiversitas, 7(1): 1014.

Yusron., dan Azwar, Moh. 2012. Pengaruh Beberapa Jenis Pupuk Hayati terhadap Pertumbuhan Semai Sengon (Paraserianthes falcataria (L) Nielsen) pada Medium Tumbuh Tanah Bekas Tambang Emas. Skripsi. Universitas Tadulako Palu. Sulawesi Tengah 